\title{
The Pesantren in Banten: Local Wisdom and Challenges of Modernity
}

\author{
Mohamad Hudaeri ${ }^{1}$, Atu Karomah ${ }^{2}$, and Sholahuddin Al Ayubi ${ }^{3}$ \\ \{mohamad.hudaeri@uinbanten.ac.id'1 , atukaromah@gmail.com², \\ sholahuddin.alayubi@uinbanten.ac.id ${ }^{3}$ \} \\ Faculty of Ushuluddin and Adab, State Islamic University SMH Banten, Jl. Jend. Sudirman No. 30, \\ Serang, Indonesia ${ }^{1}$ \\ Faculty of Syariah, State Islamic University SMH Banten, Jl. Jend. Sudirman No. 30, Serang, Indonesia ${ }^{2}$ \\ Faculty of Ushuluddin and Adab, State Islamic University SMH Banten, Jl. Jend. Sudirman No. 30, \\ Serang, Indonesia ${ }^{3}$
}

\begin{abstract}
Pesantrens (Islamic Boarding School) are Islamic educational institutions in Indonesia that are timeless, because of their adaptability to the development of society. These educational institutions develop because they have the wisdom to face changes and the ability to adapt to the challenges of modernity. During the colonial period, pesantren adapted to local culture so that Islam could be accepted by the Banten people, as well as a center of resistance to colonialism. Whereas in contemporary times, pesantren adapted to the demands of modern life. Although due to the challenges of modernity there are various variants of the pesantren model, it is related to the emergence of religious ideology in responding to modernity. The ability of pesantren in adapting to facing challenges can't be separated from the discursive tradition in Islam so that the scholars can negotiate between past practices as a reference with the demands of the age faced and their future.
\end{abstract}

Keywords: pesantren, madrasa, Banten, a discursive tradition.

\section{Introduction}

Although Islamic educational institutions (madrasa and pesantren) have an important role in the Muslim community in Indonesia and in other Muslim countries, academic studies that discuss them are still relatively few. Proponents of the modernization thesis assume that along with economic and social development in Muslim societies, the influence of religion (Islam) on social life, including its educational institutions, will decrease significantly. Madrasa and pesantren will hold the status of historical relics. For this reason, relatively few contemporary scholars pay attention to these studies of Islamic educational institutions. They prefer to talk about modernist or Islamist groups, which are seen as the emergence of a new age. But the predictions made by supporters of the modernization thesis were apparently not proven. Although policies in Muslim-majority countries often do not support its existence, even ignoring or forcibly closing it, the number of pesantren and madrassa have increased substantially, a phenomenon that continues to this day [1].

Although it was discovered about studies by scholars about Islamic educational institutions, the mindset used is based on the experience of Western countries in the process of modernization, not from the perspective and experience of Muslims themselves. So that 
madrasa and pesantren are often labeled traditional or anti-modern. Especially with the occurrence of incidents of violence and bombings in various places in the world carried out by supporters of the Taliban in Afghanistan and ISIS (Islamic State of Iraq and Syria), some of which came from alumni of Islamic educational institutions. So madrasa and pesantren are considered as a source of radical Islamic movements, militant, fundamentalist [2].

Such thoughts, which often arise in the minds of some scholars in understanding the development of Islamic education in Banten, especially regarding pesantren and madrasa. Even though the Islamic educational institution has unique wisdom and potential in responding to all the challenges of modernity so that it can still survive and continue to grow until now.

Pesantren as a religious education institution has an important position in the people of Banten in the past and the present. Before the twentieth century, the pesantren was the only formal education in Java and only taught religious knowledge, precisely transmitting traditional Islamic sciences contained in the classical books (known as the Kitab Kuning) written by scholars centuries ago.[3] But now, along with social, political and economic changes in Indonesia, some pesantren, including in Banten, have experienced many changes, both in terms of objectives, curriculum, management, number of students and their political role. Some pesantren no longer only teach religious knowledge but also secular knowledge.[4] Based on the Banten Province Islamic Boarding School Silaturrahim Forum (FSPP) in 2015, there were 3,405 pesantren in Banten with 71,971 students, with various variants.

This paper describes the development of Islamic education in Banten namely: pesantren and its relation to community development, namely about the existence of a strong relationship between pesantren with the local culture of Banten and contemporary challenges, especially related to the learning system and the role of pesantren in the community. This study also explains that the existence of various pesantren variants is a reflection of the diversity of religious ideologies in Muslim society in understanding Islamic teachings in this contemporary era.

\section{Literature review}

Although Banten is known as a devout Muslim area, studies of Islamic discourse, practice, and institutions in Banten are still few. Studies on Banten so far have been carried out around the history and culture of violence, magic and local beliefs such as; Sartono who studied the resistance of farmers in Banten against Dutch colonialism [5], Atu Karomah that had investigated about Jawara and the culture of violence in Banten [6], Ayatullah Humaeni has studied the culture and religious systems of the people of Banten [7], and Gabriel Facal which explains silat martial ritual, which contains the practice of the fight, therapy, dance, music and theater [8].

While the study of religious institutions, such as pesantren in Banten has not been done much. Studies on pesantren have been carried out outside Banten, such as in East Java or West Java, such as; Zamakhsyari Dhofier has studied Pesantren Traditions in East Java [9] and Manfred Ziemeck has discussed Pesantren in Social Change in West Java [10]. 


\section{Methodology}

This study not only uses historical data but also data from observations of several pesantrens and madrasas in Banten, interviews with various parties and studies of written sources on the development of Islamic education in Banten that have been carried out by experts. Although using traditional and modern terms to identify the development of pesantren interactions with other cultures should not be read dichotomies but it should be understood as part of a discursive tradition in Islamic societies [11]. So, the traditional and modern terms used in the pesantren variant are not interpreted as opposites but the two types of pesantren have different dimensions in the system and method of learning.

Islam as a discursive tradition means that the Muslim community always has a dialogue with the environment it faces. They try to find the legitimacy of their religious practices by returning to references that are considered authoritative, both in the texts of the Scriptures (Quran and Hadits) as well as in their past traditions. Therefore, tradition does not mean a set of doctrines and cultural facts that cannot be changed, something that is static and opposed to ratio, but tradition is the basis for transformation in conforming to current demands, without losing its authenticity with the past. Therefore, Muslim societies always negotiate between past practices as a reference with present demands and hopes for the future. As a discursive tradition, Islam teaches its adherents to always look for the correct forms of religion and to find goals in the practice of religious teachings.

\section{Result and finding}

\subsection{Pesantren relations with the local culture}

In fact, studying pesantren not only studies educational institutions but also must examine the lives of the people around them. Many individuals and institutions, directly or indirectly, are involved in pesantrens. Many Pesantren are the center of an orbit of the life of the wider community around it so that many pesantrens become the center of the social life of the Nusantara Muslim community.[10] Because it examines the values, educational activities in the pesantren and the changes that occur therein, it actually also examines aspects of community life at large, especially in the competition of religious ideologies, religious discourse and the formation of imagined Muslim subjects, within the scope of the Banten Muslim community and Indonesia.

Many experts claim that the pesantren came from the pre-Islamic education system in the archipelago, namely the boarding system used by Hindu-Buddhist priests to teach their religious teachings to their followers.[12] However, it is clear that what is taught in the pesantren and the methods it uses are sourced from orthodox Islamic teachings and the Sufistic education system that is commonly found in the Middle East.[13] Thus pesantren is an educational institution established by the kiai by using local sources and oriented to the learning process of Islam.

The Banten people have indeed been known from a long time ago to be obedient in carrying out their religious obligations compared to other local communities in Java. This not only involves religious rituals such as fasting Ramadan and paying alms (zakat) but also in social politics. However, that does not mean there are no local elements in the diversity of the community. The religious style of the Banten people from the beginning was more likely to be 
Sufistic, so they were very accommodating of local culture.[14] So that there were known practices of magic in Banten society, from a long time ago, such as; debus, pencak silat and elmu hikmat.[8] The source of this magical practice is from the tariqa (Islamic mysticism or Sufi orders) tradition and local traditions, namely jangjawokan [15].

On that basis, it is not something strange, if, in some pesantren, the Kiai not only teaches his students the sciences related to religion, such as the science of jurisprudence (fiqh), theology (kalam), the Qur'an and Tafseer, Hadith but also related to supernatural powers or magic. The source of learning is not only from the tariqa teachings, such as the Rifaiyyah and Qodiriyah wa Naqsyabandiyah but also from the local traditions of the Banten people [16].

Although there are no definitive data about the early development of pesantren in Banten before the 18th century, the process of learning Islam in Banten has been formed since the establishment of the sultanate of Banten. In the Sajarah Banten, it was stated that the process of learning about Islam during the Banten sultanate took place in the palace, which was followed by the royal family. So that it was known by several people from the sultan's family, such as Maulana Muhamad and Kiai Dukuh (Pangeran Kasunyatan) that they were known as an expert in understanding the teachings of Islam [17]. It is also related that in the sultanate of Banten, the position of Qadhi (Islamic jurist), was very influential, not only have a role in resolving religious affairs and legal issues but also in the royal succession.

The experts did state that in the early days of the development of Islam in the archipelago, including Banten, showed a unique thing that influenced the Islamic understanding in the archipelago society namely Islamization taking on a "king-centric", in the sense that the ruler was the center of power for the initial conversion process and public culture that should be emulated by his servant and the people at large. Records of the early period of Islam in the Banten region are full of stories of supernatural powers, dreams, healings, or other supernatural events that local rulers possessed to embrace Islam, such as the story of Maulana Hasanuddin who succeeded in conquering Hindu-Buddhist teachings through fighting cockfighting, and the magic story of Haji Mangsur (Shaykh Mansur) in Islamizing the southern Banten region [15].

After receiving the gift of karomah or the miracle, the authorities ordered their people to accept the new faith. However, above all, the important position of the ruler in Islamic life is expressed in large public ceremonies or celebrations, such as the celebration of the birthday of the Prophet Muhammad and the granting of titles of power and religion (such as the title of sultan and maulana) which gives a tangible form to his claim that imperial government is not only deal with worldly (secular) matters but also issues concerning the religious affairs of Muslims community [18].

The "king-centric" face of the Islamization process is not unique to Banten or Indonesia society, but similar things are also found throughout the Asian-Muslim world from Central Asia and India to the Malay islands. But what's interesting about this is that as explained by Anthony Reid that makes Islam a source of new legitimacy in political power. Far from ideological conflicts with Islam, the kingdom found new ways to express its power in Islamic terms.[19] The rulers felt that their religiosity was exemplary by their people because they supported the existence of Islamic religious learning circles in the royal palace or mosque. Such a view has caused the graves of the kings of Banten to be visited by pilgrims to get their blessings and are considered a source of karomah.

The process of Islamization which tends to be king-centric does not mean that Islam is nothing more than a "veneer" on the Hindu-Buddhist substrate.[20] Islam is only considered as an outer layer only, while the contents are still Hindu-Buddhist. This metaphorical "veneer" ignores the sociological fact that temples and monasteries of Hindu-Buddhist worship in 
Banten were almost totally destroyed in the centuries following the conversion of local authorities to Islam [5].

Although Islam has become the official religion of the kingdom in Banten that does not mean eliminating the broader landscape of knowledge about diverse Islamic understandings; knowledge and appreciation of popular religion, which is embraced by the wider community continues to grow. Because of this, we can still find pre-Islamic exorcism traditions, belief in the strength of spirits on land and at sea in several places in Banten such as; the ritual of preserving earth (ruwatan bumi) and sea celebration (sedekah laut). Even in some cases, it tries to be adapted as part of Islamic spirituality.

When the Sultanate of Banten suffered a setback along with the entry of Dutch colonialism in Banten at the end of the 16th century, major changes occurred in the social, political and economic order which greatly influenced the process of changing Islamic learning. The process of Islamic education is no longer in the royal palace and sponsored by the sultan, but moved to the periphery carried out by religious experts (kiai) who were separated from power. The pesantren has been a well-established independent institution. Because in the era of the sultanate of Banten, there were no Islamic educational institutions, such as independent pesantren, as places for further Islamic learning until the mid-eighteenth century. Previously, the process of deep learning of Islam was only offered in court and under the protection of the authorities. Thus, in most areas in Banten and other parts of Java, the emergence of rural kiai and pesantren was a phenomenon that only developed in the eighteenth century.

The pesantren has found the support of the Muslim community by giving their alms (zakat) to the kiai or tariqa (Sufi orders) teachers, not to the rulers appointed by the Dutch colonial government. The pesantren became a protective institution for the public from the penetration of colonialism, and it was not infrequently the center of resistance against the Dutch government. This is reflected in the events of resistance by the kiai and tariqa teachers, which culminated in the "Cilegon rebellion".[5] At that time, Islamic learning material in pesantren was very ideological, namely to carry out resistance to the colonial government. The kiai and tarekat teachers not only taught their students the normative Islamic doctrine, as a way of life towards Allah but also used the sciences of magic to fight the Dutch colonialism. Magism is not only derived from the tariqa but also taken from the local traditions of Banten.

\subsection{Pesantren relations with the modernity}

In the early days of Indonesian independence, many scholars, especially modernists, saw pesantren as an obstacle to the development of modern Muslim societies because of their attachment to Islamic classical schools in the thought of fiqh (Islamic legal) and kalam (Islamic theology) and their sufistic orientation in practical action. The kiai, as pesantren leaders, were seen as more busy defending centuries-old religious practices than thinking about ways to adapt to the development of modernity [21].

Such a view denies the active role of kiai and the changes taking place in pesantren in order to respond to the political and economic transformation taking place in Indonesia. Pesantren in responding to the challenges of modernity have a unique and different way from other Islamic groups that tend to be revolutionary and radical. Pesantren make changes slowly and carefully so that these changes do not cause noise and can run peacefully [9].

Changes in the pesantren education system in Banten occurred at the beginning of the 20th century. This was marked by the establishment of Mathlaul Anwar in 1916 by K.H. Mas 
Abdurrahman bin Mas Jamal in Menes, Pandeglang. He applied the madrasa (school) system, which has a general learning curriculum and grade level, without neglecting the religious lessons that have been used in pesantren [22]. In the following nine years, in 1925, another pesantren in Banten, Al-Khaeriyah was founded by K.H. Sham'un bin H. Alwiyan in Citangkil, Cilegon [23]. The two pesantren also change their learning process by including general lessons and grade levels. In the later period, they became the centers of the madrasa networks built by its alumni.

The development of the madrasa system for advanced Islamic learning processes is driven by several factors. First, the emergence of colonial government policies on "ethical politics". The Ethical Policy focuses on improving the lives of colonized peoples by developing economic sectors and opening access to education for colonizers [24]. In the 1900s began to open schools intended for the natives, both for the nobility and ordinary people. But the curriculum taught in the Dutch school is entirely secular, not teaching things related to Islamic learning. So that graduates from these schools do not know much about Islamic teachings.

Second, the development of the religious reform movement which emphasized the need to purify Islamic teachings from practices that did not originate from Islamic traditions, especially those from local traditions. This movement is carried out by the Muslim archipelago who has studied in the Middle East. The religious reform movement spearheaded by Mohammed Abduh in Egypt and Muhammad ibn Abd al-Wahhab in eighteenth-century Arabia. Both of these figures inspired many archipelago Muslims, including Banten, to carry out renewal in religious understanding, including in the changing education system [25]. Especially with the increasingly easy journey to the Middle East and Southeast Asia itself as a result of the expansion of European power in the late eighteenth and early nineteenth centuries, more and more muslim student's archipelago, particularly Bantens, were studying in the Arab world. Even according to Christiaan Snouck Hurgronje's notes, it was concluded that Java (the name given to Southeast Asians in the Arab lands) formed the largest community in the holy city, Mecca. In 1927, 64,000 pilgrims from the Dutch East Indies and British Malaya made the pilgrimage, comprising 42 percent of foreigners in Mecca [26].

Pesantren in Banten has been developing along with the changes that occur in society due to modernization and the emergence of various variants of religious ideology. As a reflection of the religious life of Muslim communities and as a response to the changes that occur, pesantren now have diversity in their forms and types. There are at least three types of pesantren variants, namely salaf (traditional), khalaf (modern) and a combination of the two.

The development of the madrasa education system caused divisions in the Muslim community. In many areas, there is new and fierce competition between the "Old People" associated with the pesantren and the "Young People" who want to build a modernist madrasa.[27] This context creates a political and educational legacy that has survived to this day. This has led to the emergence of the terms of traditional pesantren (salaf pesantren) and modern pesantren (khalaf pesantren).

Salaf pesantren is a traditional Islamic boarding school that has the characteristics of the students living and staying in the cottage (pondok), in teaching there is no definite curriculum used and they still use the methods of teaching sorogan (individual learning) and bandongan (learning together). Kiai's role is very large and has full authority in the teaching and learning process. All material taught in this pesantren is entirely about religious teachings sourced from Arabic books (known as Kitab Kuning) written by medieval scholars. Examples of this model boarding school in Banten are the Pesantren Thohariyah in Pandeglang Regency and the Pesantren Pelamunan in Serang Regency. 
Khalaf pesantren is a modern Islamic boarding school that includes general subject matter (secular science) in their teaching, in addition to Islamic subject matter. This pesantren uses the curriculum commonly used by madrassas (schools characterized by Islamic values under the auspices of the Ministry of Religion) or public schools (schools under the auspices of the Ministry of National Education) at various levels. Students learn not only religious knowledge but also natural and humanities. The religious curriculum that is used no longer uses classical books (Kitab Kuning), but instead uses books written by contemporary scholars. In this type of pesantren, the kiai no longer has full authority in the learning process but has been delegated to the teachers (ustadz). This pesantren model is seen as a form of integration of religious science with general sciences (humanities, social and natural sciences). Examples of this model boarding school are the Daar El-Qolam Pesantren in Tangerang Regency and the La Tansa Pesantren in Lebak Regency.

The third model is the combination of the two pesantren models, combining the traditional pesantren and public-school system. The students follow two models of the learning process. The patterns and methods commonly used in traditional pesantren are used in the process of learning religious knowledge, especially in studying classical books (Kitab Kuning). While the public-school system is used to obtain general knowledge (humanities and science). An example of this model boarding school is the Qothrotul Falah Pesantren in Lebak Regency.

The number of pesantren in Banten is based on the record of the Forum Silaturrahmi Pondok Pesantren (FSPP) or Islamic Boarding School Communication Forum Banten in 2015 there were 3,405 pesantren with 71,981 students. It consists of 3,096 Salafi pesantren (traditional), 80 modern schools and 220 pesantren a combination of both. In fact, according to the Ministry of Religious Affair's record to date, more than $70 \%$ of pesantren have operated formal education, while the rest have given students access to formal education outside of pesantren. At present, there are very few pesantren that still survive while maintaining their style and function in the pesantren a century ago.

The differences in the pesantren education system developed by the ulama (religious scholar or kiai) show that there are differences in the religious understanding of authority, religious orthodoxy, tradition, and individual formation. A traditional pesantren is founded and managed by kiai who have a tendency of the traditional understanding of Islamic teachings, while modern boarding school is founded and managed by $\mathrm{f}$ the group of religious scholars that tends to understand Islamic teachings from the group of modernists. The emergence of the two tendencies of religious ideology cannot be separated from the current development of modernity that is overwhelming Muslims.

The proponent of modernist Islamic orthodoxy (Kaum Muda) is of the view that the Alquran and the Sunnah are complete instructions to guide the lives of every Muslim and emphasize the importance of the moral responsibility of each individual. Every Muslim has access to read and interpret the Quran and Sunnah if they have the intellectual ability to do so. They strongly reject the authority of other religious texts, such as the work of classical scholars. Whereas on issues that are not clearly explained in the Scriptures, such as about Science, economics and the education system are open things that every Muslim can do in accordance with his wishes. Therefore, Muslim modernists emphasize the importance of being rational and autonomous in understanding the scriptures and being active in social life. Based on this, the curriculum applied in modern boarding schools, in addition to the basic Islamic sciences, also adapts modern sciences, such as natural science, social sciences, and humanities. 
While supporters of traditional pesantren (Kaum Tua) emphasize the authority of the opinions of the classical scholars listed in the classic books (Kitab Kuning). They argue that words or sentences in the Quran cannot be directed by every Muslim because often the verses of the Quran mean ambiguous, not transparent or very clear as understood by modernists. This is reflected in the often-encountered differences in the scholars in interpreting the verses of the Quran. In order to avoid mistakes, it is very important to lean on or hold on to the opinion of authoritative scholars. Based on that, the curriculum in the Salafi pesantren emphasizes the study of classical books (Kitab Kuning).

However, the challenges of modern society's life patterns forced the salaf pesantren managers to develop an education system separate from the pesantren, namely by opening a public education system that teaches natural science, social sciences, and humanities, so that graduating pesantren can adapt to the demands of modern life. This has led to the emergence of a combination boarding school model.

\section{Conclusions}

The study contained in this paper provides several conclusions. First, in general, Islamic education in Banten moves dynamically, changing with changes in society. Even the Islamic education system has changed very far during this century. Initially, the Islamic education system was only "king-centric", that is, the process of learning about Islamic teachings was only supported by the sultan (king) and took place in the palace, which was followed by the royal family or the nobility. This relates to the process of Islamization that the ruler is the center of power for the initial conversion process and public culture that should be emulated by the people. But with the collapse of the Banten sultanate along with the occurrence of Dutch colonialism in Banten, the face of the "king-centric" Islamic education underwent a significant change. The process of Islamic education is no longer in the royal palace and sponsored by the sultan, but moved to the outskirts carried out by religious experts (kiai) who are free from power. The pesantren plays a role as a religious education institution that seeks to be a protector of the Islamic community from the penetration of colonialism and is not infrequently the center of resistance against the Dutch colonial government.

Second, along with changes in the Dutch colonial government's policy of introducing the school education system to the natives and with the increasingly intense relations between archipelago (Nusantara) students, including those who came from Banten, with religious reform movements in the Middle East (Arabia and Egypt), the pesantren system was challenged by the introduction of the madrasa education system. Changes in the pesantren education system in Banten occurred marked by the establishment of Mathlaul Anwar in 1916 and Al-Khaeriyah in 1925. Both pesantren used the madrasa system in the learning process and included general lessons. The development of the madrasa system in Islamic education was against the monopoly of the previous pesantren education system which taught religious teachings which originated in classical books, especially the yellow books (Kitab Kuning). In addition, these changes have caused the effects of division and competition in the Muslim community between old generation (traditional group) and young generation (modernist group).

Third, there are various variants in the development of Islamic boarding schools in Banten showing the existence of religious ideological differences that occur in Muslim communities. These ideological differences arise due to modernization which not only

concerns the issue of attitudes towards science and technology but also concerns issues of 
tradition, the authority of behavior and social structure. In the end the issue of what kind of Muslim individual or subject will be formed by pesantren education institutions in facing the challenges of modern life that distinguish the kiai and managers of pesantren in determining the form of pesantren that they manage; salafi, khalafi or a combination of both.

\section{References}

[1] F. A. Noor, Y. Sikand, and M. van Bruinessen, The Madrasa in Asia: Political Activism and Transnational Linkages. Amsterdam, Netherlands : Amsterdam Univ. Press, 2008.

[2] J. Malik, Madrasas in South Asia: Teaching Terror? Routledge, 2007.

[3] M. van Bruinessen, Kitab Kuning, Pesantren, dan Tarekat: Tradisi-tradisi Islam di Indonesia. Bandung: Mizan, 1995.

[4] S. A. Buresh, Pesantren-based Development: Islam, Education, and Economic Development in Indonesia. University of Virginia, 2002.

[5] S. Kartodirdjo, Pemberontakan Petani Banten 1888. Jakarta: Pustaka Jaya, 1984.

[6] A. Karomah, "Jawara dan Budaya Kekerasan pada Masyarakat Banten," Uiversitas Indonesia, Jakarta, 2004.

[7] A. Humaeni, Budaya dan Religi Masyarakat Ciomas Banten. Serang - Banten: Laboratorium Bantenologi UIN Sultan Maulana Hasanuddin Banten, 2017.

[8] G. Facal, Keyakinan dan Kekuatan: Seni Bela Diri Silat Banten. Yayasan Pustaka Obor Indonesia.

[9] Z. Dhofier, Tradisi Pesantren: Studi tentang Pandangan Hidup Kyai. Lembaga Penelitian, Pendidikan, dan Penerangan Ekonomi dan Sosial, 1982.

[10] M. Ziemeck, Pesantren dalam Perubahan Sosial. Jakarta: P3M, 1986.

[11] T. Asad, “The Idea of an Anthropology of Islam," Qui Parle, vol. 17, no. 2, pp. 1-30, 2009.

[12] M. C. Ricklefs, A History of Modern Indonesia Since C. 1200. Stanford University Press, 2001.

[13] J. L. Esposito, Islam: The Straight Path. Oxford University Press, 1988.

[14] M. A. Tihami, "Kyai dan Jawara Banten: Keislaman, Kepemimpinan dan Magic," Refleksi J. Kaji. Agama Dan Filsafat, vol. 14, no. 1, 2015.

[15] M. Hudaeri, "Tasbih dan Golok: Kedudukan dan Peran Kiyai dan Jawara di Banten," Alqalam, vol. 20, no. 98-99, pp. 141-172, 2003.

[16] A. Ahmad, Ilmu Hikmat di Banten, Studi Kasus Praktik Islam Mistik di Serang. Serang: Yayasan Seng Pho Banten, 2007.

[17] H. Djajadiningrat, Tinjauan Kritis tentang Sajarah Banten. Jakarta: Djambatan, 1983.

[18] M. R. Woodward, Islam in Java: Normative Piety and Mysticism in the Sultanate of Yogyakarta. University of Arizona Press, 1989.

[19] A. Reid, Southeast Asia in the Age of Commerce, 1450-1680: Expansion and crisis. Yale University Press, 1988.

[20] C. Geertz, The Religion of Java. University of Chicago Press, 1976.

[21] D. Noer, Gerakan Moderen Islam di Indonesia 1900 - 1942. Jakarta: PP3ES, 1985.

[22] Maftuh, "Pembaharuan Pendidikan Islam di Banten Awal Abad XX: Studi atas Mathla'ul Anwar dan Al-Khairiyah," Anal. J. Studi Keislam., vol. 11, no. 2, pp. 273-312, 2011.

[23] A. D. Afif, "Dinamika Sistem Pendidikan Al-Khariyah: Suatu Kajian tentang Arah Pembinaan dan Pengembangan dari Visi Keunggulan," Fakultas Syari' ah IAIN "SGD” di Serang, 1977.

[24] R. van Niel, The Emergence of the Modern Indonesian Elite. Brill, 1960.

[25] R. W. Hefner, Making Modern Muslims: the Politics of Islamic Education in Southeast Asia. University of Hawaii Press, 2009.

[26] C. S. Hurgronje, Mekka in the Latter Part of the 19th Century: Daily Life, Customs and Learning of the Moslims of the East-Indian-archipelago. Brill, 1931.

[27] J. R. Bowen, Muslims through Discourse: Religion and Ritual in Gayo Society. Princeton University Press, 1993. 